\title{
IMPLEMENTASI KEBIJAKAN PERENCANAAN PENATAAN TOKO MODERN BERJARINGAN NASIONAL DI KABUPATEN SLEMAN DALAM STUDI EKONOMI POLITIK
}

\author{
Ita Mutiara Dewi \\ FIS Universitas Negeri Yogyakarta \\ email: itamutiaradewi@gmail.com
}

\begin{abstract}
Abstrak: Implementasi Kebijakan Perencanaan Penataan Toko Modern Berjaringan Nasional di Kabupaten Sleman dalam Studi Ekonomi Politik. Penelitian ini bertujuan untuk (1) mengidentifikasi implementasi kebijakan perencanaan penataan toko modern berjaringan nasional di Kabupaten Sleman; (2) mengetahui peran pemerintahan lokal dalam implementasi kebijakan tersebut; (3) merumuskan rekomendasi kebijakan agar implementasi dapat berjalan dengan baik. Penelitian menggunakan metode kualitatif, studi kasus dan analisis kebijakan digunakan untuk mengeksplorasi, menganalisis dan melakukan intepretasi data-data penelitian. Analisis Environment Value and Resources (EVR) congruence, teori pilihan publik dan pilihan rasional, kebijakan rasional elit (top down) dan deliberatif (bottom up). Hasil penelitian ini menunjukkan: (1) implementasi Kebijakan Perencanaan Penataan Toko Modern Berjaringan Nasional kurang berjalan dengan baik disebabkan kurangnya sinergi EVR akibat implementasi yang bersifat pilihan rasional dan top down; (2) peran pemerintah dapat dikatakan sebagai regulator (pembuat aturan saja) yang ditunjukkan dengan formulasi dan implementasi yang kurang melibatkan partisipasi kelompok kepentingan seperti LSM dan masyarakat akhirnya kebijakan menjadi kurang pro poor dan pro public (3) rekomendasi implementasi kebijakan agar berjalan dengan baik yaitu dengan mensinergikan EVR, implementasi yang bersifat bottom up dan deliberatif, mereposisi peran pemerintah sebagai pelayan masyarakat, partisipasi dan pemberdayaan masyarakat dan kelompok untuk mengawal dan advokasi kebijakan sehingga kebijakan pro poor dan pro publik.
\end{abstract}

Kata kunci: kebijakan publik, ekonomi politik, pemerintah lokal, tradisional-modern

Abstract: Implementation of Policy Planning Planning at the National Networked Modern Stores in Sleman in the Study of Political Economy. This study aims (1) to identify policy implementation of restriction's policy of national networking modern retail stores in Sleman district, (2) determine the role of local government in the implementation of the policy, (3) formulate policy recommendations that the implementation can run well. This study used qualitative methods, case studies and policy analysis are used to explore, analyze and interpret research datas. This reseach use Environment Value and Resources (EVR) congruence analysis, public choice and rational choice theory, rational policy elite (top-down) and deliberative (bottom-up). The results showed that: (1) the implementation of restriction's policy of national networking modern retail stores is not run well due to unsynchronized EVR and the implementation tend to be rational choice or top down, (2) the role of the government can be said as regulator (a rule makers) as indicated in the formulation and implementation stage which involves less participation of interest groups such as NGOs, hence the public policy eventually become pro-elite or decision maker (3) the implementation of the policy will run properly if EVR congruences, policy implementation tend to be top down and deliberative. Its need reposition the role of government as a public servant, advocacy groups participation and community empowerment to oversee policy implementation so that the policies become pro-poor and pro-public.

Keywords: public policy , political economy , local government, traditional - modern 


\section{PENDAHULUAN}

Keberadaan toko ritel modern di Kabupaten Sleman merupakan permasalahan penting karena di satu sisi menyerap lapangan pekerjaan, di sisi lain mengancam keberadaan usaha toko ritel tradisional, sehingga permasalahan kemiskinan dan lapangan pekerjaan tidak teratasi namun bertambah runyam. Hal ini disebabkan sekitar $10 \%$ dari total penduduk Indonesia menggantungkan hidupnya dengan berdagang eceran/ritel. Karakteristik industri ritel yang tidak membutuhkan keahlian khusus serta pendidikan tinggi untuk menekuninya, menyebabkan sebagian penduduk Indonesia terutama yang tergolong kategori UKM masuk di industri ritel ini. Pedagang-pedagang kecil ini yang dalam perkembangannya mendominasi jumlah tenaga kerja industri ritel di Indonesia. Pedagang-pedagang ini menjadi pedagang pasar tradisional, pedagang toko kelontong bahkan masuk ke industri informal yaitu Pedagang Kaki Lima (PKL). Para pedagang inilah yang disebut sebagai pedagang eceran/ritel tradisional.

Pusat Studi Ekonomi Kerakyatan UGM dan Lembaga Ombudsman Swasta (LOS) DIY telah melakukan studi dalam konteks Yogyakarta. Secara umum terdesaknya pedagang pasar tradisional atau pebisnis ritel lokal, di antaranya dalam bentuk menurunya omset penjualan. Penelitian ini menemukan penurunan rata-rata sebesar $-5,9 \%$, namun penurunan yang lebih besar dialami oleh kelompok pedagang dengan aset antara Rp 5-15 juta, Rp 15-25 juta, dan di atas Rp 25 juta, yang masingmasing mengalami penurunan sebesar $-14,6 \%,-11 \%$, dan $-20,5 \%$. Berdasarkan kewilayahan, penurunan omset tertinggi dialami oleh pedagang di Kota Yogyakarta 25,5\% dan Kabupaten Sleman - 22,9\% (Santosa dan Indroyono, 2011).

Seperti halnya pemerintahan daerah/ lokal lain, Kabupaten Sleman pun telah memiliki peraturan khusus berkaitan dengan ritel modern, yaitu Peraturan Bupati Sleman Nomor 13 Tahun 2010 tentang Penataan Lokasi Toko Modern dan Pusat Perbelanjaan dan Peraturan Bupati Sleman Nomor 45 Tahun 2010 tentang Perizinan Pusat Perbelanjaan dan Toko Modern.

Namun, keberadaan peraturan daerah tersebut tidak terlalu berjalan efektif terbukti dengan masih adanya kasus masyarakat yang menginginkan ditutupnya toko modern di lingkungannya. Sebagai contoh kasus yang terjadi di Dusun Prayan, Kelurahan Condong Catur, Kecamatan Depok, Kabupaten Sleman, DIY (Prenanto, 2011) dan Dusun Cepet, Desa Purwobinangun, Kecamatan Pakem, Kabupaten Sleman, DIY. Sebuah toko modern berjaringan nasional yang terdapat di wilayah tersebut ditutup paksa oleh warga sekitar, meskipun sebelumnya Satpol PP telah melakukan penutupan. Paguyuban Warga Purwobinangun dan Gapoktan Pulowatu juga telah mengadukan ke Bupati Sleman. Toko modern tersebut telah melanggar peraturan daerah karena tidak memiliki IMB, HO, maupun SIUP (Antara, 2011).

Selain itu, ratusan pedagang Pasar Godean yang tergabung dalam Paguyuban Pedagang Pasar Godean, Sleman, berunjuk rasa di kantor DPRD setempat, pada hari Selasa, 6 Maret 2012. Pedagang memprotes maraknya mini market di sekitar pasar, hingga mengakibatkan jumlah pembeli di pasar tradisional menurun drastis. Bahkan, tidak jarang dagangan mereka tidak bisa laku satu pun. Padahal, mereka tetap dibebani membayar restribusi. Berdasarkan Peraturan Bupati Nomor 45 Tahun 2010, pasar modern atau mini market ditetapkan minimal berjarak 500 meter dari pasar tradisional. Kenyataannya, dua mini market berjaringan berdiri sekitar 50 meter dari Pasar Godean (Liputan6. com, 2012). Hal ini menunjukkan bahwa regulasi berkaitan penataan lokasi dan 
perizinan tidak berjalan efektif yang terbukti dengan keberadaan toko modern yang tidak sesuai tata ruang maupun muncul tanpa izin.

Sampai tahun 2013 ini belum pernah terdengar kabar tentang pemberian sanksi terhadap keberadaan toko modern berjaringan nasional tersebut. Hal ini menunjukkan bahwa implementasi kebijakan pembatasan toko modern berjaringan nasional di Kabupaten Sleman ini kurang berjalan dengan baik.

Tabel 1. Beberapa Isu Pelanggaran Ritel Modern di Sleman

\begin{tabular}{|c|c|c|}
\hline $\begin{array}{c}\text { Jenis } \\
\text { Pelanggaran }\end{array}$ & Penjelasan & Jml \\
\hline $\begin{array}{l}\text { Pelanggaran } \\
\text { Regulasi } \\
\text { Tata Ruang }\end{array}$ & $\begin{array}{l}\text { Sejumlah ritel modern } \\
\text { tidak memenuhi jarak } \\
\text { minimal } 500 \text { meter } \\
\text { dari pasar }\end{array}$ & 22 \\
\hline $\begin{array}{l}\text { Pelanggaran } \\
\text { Regulasi } \\
\text { Perizinan }\end{array}$ & $\begin{array}{l}\text { Sejumlah ritel modern } \\
\text { menjalankan usaha } \\
\text { tanpa izin }\end{array}$ & 40 \\
\hline
\end{tabular}

Sumber: Diolah dari Disperindag Sleman (2011)

\section{METODE}

Penelitian ini menggunakan metode analisis kebijakan (policy analysis method) yang mengarahkan hasil studi komprehensif menjadi pertimbangan utama bagi perumus kebijakan dalam formulasi kebijakan. Metode analisis kebijakan mengkaji kebijakan dan instrumen-instrumen yang digunakan oleh pemerintah, khususnya aspek jenis dan instrumen kebijakan yang bisa memecahkan masalah publik yang ada, dalam arti kebijakan apa yang perlu diambil atau dilakukan oleh pemerintah agar tujuan yang ingin dicapai dapat terwujud secara efisien (Imawan, 1999: 4).

Nasution (1982:31-38) menjelaskan bahwa studi kasus (case study) adalah suatu penelitian yang dilakukan secara intensif, terinci dan mendalam terhadap suatu organisme, lembaga atau gejala tertentu. Selanjutnya dijelaskan bahwa studi kasus merupakan bentuk penelitian yang mendalam tentang aspek lingkungan sosial termasuk didalamnya manusia. Pada dasarnya tujuan penelitian kasus adalah mencoba memberikan gambaran yang jelas mengenai karakteristik khas dari suatu kasus yang diteliti dengan memberikan gambaran dan peristiwa apa adanya.

Frey et.al (Mulyana, 2001:20) menjelaskan bahwa pendekatan studi kasus menyediakan peluang untuk menerapkan prinsip umum terhadap situasi-situasi spesifik atau contoh-contoh yang disebut kasus-kasus. Selanjutnya Ragin (Mulyana, 2001:203) menyatakan bahwa metode berorientasi kasus bersifat holistik, metode ini menganggap kasus sebagai entitas menyeluruh dan bukan sebagai kumpulan bagian-bagian (atau kumpulan skor mengenai variabel).

Pengumpulan data penelitian ini dilakukan dengan cara observasi, wawancara mendalam dan dokumentasi dari sumber primer yaitu pihak-pihak yang terkait dalam implementasi kebijakan terutama Dinas Perdagangan, Perindustrian dan Koperasi (Disperindagkop) serta sumber sekunder berupa artikel dari surat kabar maupun jurnal.

Sedangkan analisis data menggunakan model analisis interaktif. Langkah-langkah analisis data dalam penelitian ini sesuai dengan yang dikemukakan Miles dan Huber-man yaitu pemilahan (reduksi) data, sajian data (data display), kesimpulan dan verifikasi serta validasi data (lihat Gambar 1).

\section{HASIL DAN PEMBAHASAN Implementasi Kebijakan Perencanaan Pe- nataan Toko Modern Berjaringan Nasional di Kabupaten Sleman}

Kebijakan perencanaan toko modern berjaringan nasional di Kabupaten Sleman berdasarkan Peraturan Bupati Sle- 


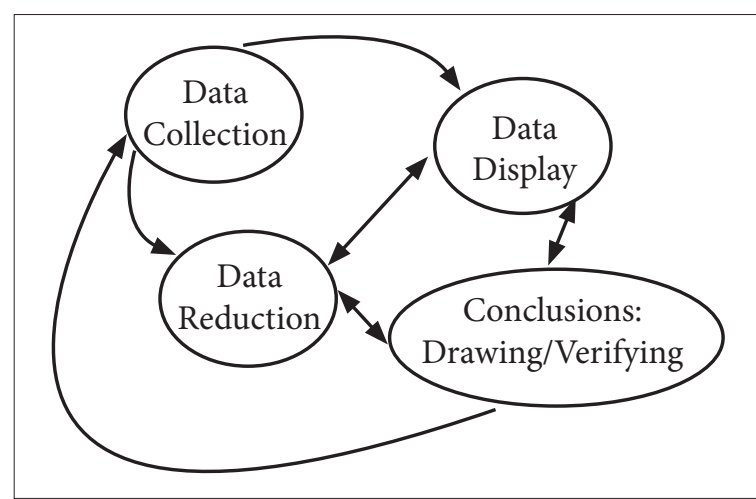

Gambar 1. Analisis Interaktif dalam Miles dan Huberman dalam Emzir (2010)

man Nomor 13 Tahun 2010 tentang Penataan Lokasi Toko Modern dan Pusat Perbelanjaan dan Peraturan Bupati Sleman Nomor 45 Tahun 2010 tentang Perizinan Pusat Perbelanjaan dan Toko Modern mengacu pada kebijakan pemerintah pusat terutama Perpres No.112 tahun 2007 tentang Penataan dan Pembinaan Pasar Tradisional, Pusat Perbelanjaan Dan Toko Modern. Salah satu peraturan yang rancu dapat dilihat dalam Perpres pasal 3 ayat (1) yang menyebutkan "Lokasi pendirian Pusat Perbelanjaan dan Toko Modern wajib mengacu pada Rencana Tata Ruang Wilayah Kabupaten/Kota, dan Rencana Detail Tata Ruang Kabupaten/ Kota, termasuk Peraturan Zonasinya." serta ayat (2) yang mengatur batasan luas lantai penjualan Toko Modern. Padahal dalam era otonomi daerah, dimana masing-masing daerah menginginkan PAD (Pendapatan Asli Daerah) instan bagi daerahnya, memungkinkan pemerintah daerah/lokal untuk menambah pendapatan melalui perizinan. Aturan ini juga masih kurang memadai untuk melindungi zona pasar tradisional. Dalam pasal 18 menyebutkan, pasar modern yang sudah berdiri tidak perlu dibongkar. Padahal kalaupun sudah berdiri, seharusnya direlokasi ke border city (di luar kota) dan harus jauh dari pasar tradisional yang ada.

Bila kebijakan nasional yang menjadi acuan kebijakan lokal agak rancu dan inkonsisten (apakah pro pengusaha atau pro publik), maka kebijakan lokal kemungkinan menjadi inkonsisten pula. Memang hal ini tidak terlepas dari fenomena pro kontra terhadap investasi atau penanaman modal asing seperti yang diungkapkan oleh Todaro. Argumen yang mendukung penanaman modal swasta asing yaitu peranan dalam mengisi kekosongan atau kesenjangan (1) sumber daya antara tingkat investasi yang ditargetkan dengan jumlah aktual tabungan domestik yang dapat dimobilisasikan; (2) antara target jumlah devisa atau kesenjangan perdagangan; (3) antara target penerimaan pajak pemerintah dan jumlah aktual pajak yang dikumpulkan; (4) di bidang manajemen, semangat kewiraswastaan, teknologi produksi dan ketrampilan kerja yang diharapkan dapat diisi sebagian maupun seluruhnya oleh perusahaan swasta asing. Sedangkan argumen yang menentang penanaman modal swasta asing yaitu: (1) perusahaan multi nasional (PMN) memang menyediakan modal namun justru dapat menurunkan tabungan maupun investasi domestik di negara tuan rumah sehubungan dengan akan terciptanya aneka bentuk persaingan yang tidak sehat yang bersumber dari perjanjian produksi ekslusif antara pihak perusahaan multi nasional dengan pemerintah negara tuan rumah; tidak terlaksananya reinvestasi atas keuntungan yang didapatkan dalam perekonomian tuan rumah; terpacunya tingkat konsumsi domestik sehingga justru menurunkan minat masyarakat setempat untuk menabung atau menginvestasikan tambahan pendapatannya; (2) dampak jangka pendek PMA dapat memperbaiki posisi devisa negara tuan rumah, tetapi dalam jangka panjang berdampak negatif yaitu dapat mengurangi penghasilan devisa dari sisi neraca transaksi berjalan maupun neraca modal; (3) PMA memberi kontribusi bagi penerimaan pemerintah dalam bentuk pajak perusahaan; (4) keterampilan dan pengalaman 
manajemen, semangat kewirausahaan, gagasan teknologi dan jaringan hubungan dagang luar negeri yang diberikan oleh PMN ternyata tidak memberikan manfaat nyata bagi pengembangan SDM dan keterampilan kerja yang masih tergolong langka di negara tuan rumah (Todaro dan Smith, 2009:266-276).

Keberadaan kebijakan pembatasan toko modern tentunya berusaha untuk melindungi kepentingan masyarakat. Usaha padat karya yang menyerap lapangan kerja termasuk di bidang perdagangan ritel merupakan tanggung jawab negara sesuai Pasal 28 UUD'45 yang menunjukkan pola organic statism. Pola organic statism ini menunjukkan state centered dimana hal ini dikaitkan dengan konsep negara kekeluargaan yang dicetuskan oleh Sukarno, Hatta maupun Soepomo. Konsep negara kekeluargaan yang dimaksud yaitu persatuan antara pemimpin dan rakyat, antara golongangolongan rakyat, diikat oleh semangat yang dianut oleh masyarakat Indonesia, yaitu semangat kekeluargaan dan semangat gotong-royong (Effendi, 2004).

Dalam perjalanannya, peran negara mulai mengalami pergeseran dari peran yang kuat "untuk lebih bertanggungjawab pada masyarakat"-meskipun dalam prakteknya terkadang berpihak kepada kepentingan pengusaha besar-menjadi society centered, negara sebagai regulator kepentingan individu maupun kelompok yang berjalan selaras dengan pasar bebas atau yang dikenal dengan neoliberalisme.

\section{Implementasi Kebijakan sebagai Pilihan Rasional}

Menurut Bardach, implementasi adalah permainan tawar menawar, persuasi dan maneuver di dalam kondisi ketidakpastian (Bardach, 1977:56 dalam Parsons 2011:472). Aktor implementasi bermain untuk memegang kontrol sebanyak mungkin dan memainkan sistem demi mencapai tujuannya. Politik adalah sesuatu yang melampaui institusi politik resmi. Implementasi adalah bentuk dari politik yang berlangsung di dalam domain kekuasaan yang tak terpilih.

Asumsi utama pendekatan rational choice adalah individu membuat pilihan dengan tujuan mengejar kepentingan pribadi. Individu harus membuat pilihan karena adanya kelangkaan barang dan jasa, waktu, energi, atau pendapatan yang terbatas. Kemungkinan pilihan juga dibatasi oleh lingkungan dan kemampuan. Pilihan tersebut juga semakin dibatasi oleh adanya aturan main perilaku, nilai, norma, undang-undang, informasi, dan harga. Pengambilan keputusan yang dilakukan akhirnya dibatasi oleh hal-hal tersebut. Oleh karena itu, para individu selalu mengambil keputusan dalam situasi terkendala.

Rational choice menerapkan metode behavioral ini untuk memahami perilaku pejabat pemerintah selaku pengambilan keputusan. Negara, seperti halnya pasar, terdiri atas para individu yang masingmasing berusaha mencari keuntungan pribadi. Diasumsikan bahwa setiap aktor politik bertindak sesuai pandangan bahwa sifat manusia adalah mengejar kepentingan sendiri. Agar kehidupan pribadinya menjadi lebih baik, para individu dalam pemerintahan membuat pilihan kebijakan yang dapat memenuhi kepentingan pribadinya, mengingat berbagai kendala yang melingkupinya, seperti kedudukannya dalam pemerintahan, undang-undang yang berlaku, para pendukung politiknya, dan informasi yang dimiliki.

Implementasi kebijakan perencanaan toko modern seperti halnya dalam proses formulasi, yaitu bersifat pilihan rasional dan top down. Perencanaan penataan toko modern merupakan kebijakan yang cukup lama diimplementasikan di Kabupaten Sleman terbukti dengan adanya Perda No.7/2006 tentang Kemitraan Pasar dan Toko Modern dengan UMKM. Oleh 
karena itu secara rasional, keberadaan Perbup No. 13 Tahun 2010 dan Perbup No. 45 Tahun 2010 merupakan kelanjutan Perda sebelumnya, apalagi kebijakan perencanaan penataan toko modern dan pusat perbelanjaan, seakan menjadi trend kebijakan di Indonesia karena hampir di setiap pemerintah lokal Kabupaten dan Propinsi di Indonesia pasti menerbitkan Perbup, Pergub atau Perda dalam beberapa dekade terakhir ini.

Selain itu hal paling mendasar bahwa suatu implementasi kebijakan disebut sebagai pilihan rasional, bukan pilihan publik ketika tidak terjadi pertukaran politik (politics as exchange) antara pemilih (masyarakat) dan yang dipilih (pembuat kebijakan dan aktor aktor yang mengimplementasikan kebijakan).

Dalam perspektif pilihan publik, proses pemilu dapat disebut sebagai pasar politik (political market), dilihat sebagai instrumen yang memungkinkan penyebaran preferensi dikombinasikan ke dalam pola atau keluaran (output). Keluaran tersebut tidak lain adalah realisasi janji-janji program dari partai politik yang memperoleh suara mayoritas (Suryono, 2006:114).

Pada masa pemilihan kepala daerah (Bupati dan Wakil Bupati) pada tahun 2005, belum ada bukti konkrit dan sulit mengukur bahwa kebanyakan pemilih berkepentingan terhadap kebijakan perencanaan penataan toko modern seperti konstituen pendukung kemenangan dari asosiasi pedagang pasar. Begitu pula pada pilkada Sleman 2010, pemilih tentunya kurang memperhatikan visi misi calon Kepala Daerah Kabupaten Sleman.

Apalagi, visi dan misi yang diusung hampir semua pasangan calon dalam kampanye pilkada Sleman, yaitu tentang upaya peningkatan kesejahteraan masyarakat atau dapat dikatakan hampir semuanya sama. Dari tujuh pasangan calon bupati (cabup) dan wakil bupati (cawabup) yang menyampaikan visi dan misinya pada sidang paripurna DPRD Sleman, semuanya mengangkat tema upaya peningkatan kesejahteraan masyarakat. Selain tema itu, mayoritas kandidat juga mengangkat isu pengentasan kemiskinan dan pendidikan dalam program kerja mereka apabila terpilih menjadi kepala daerah, serta peningkatan pelayanan kesehatan bagi masyarakat khususnya keluarga miskin.

\section{Implementasi Kebijakan Top Down}

Implementasi yang bersifat pilihan rasional tentunya berkaitan erat dengan pembuat kebijakan dan birokrasi/ aparat yang mengimplementasikannya. Implementasi yang bersifat top down ditunjukkan dengan adanya bukti bahwa Lembaga Ombudsman Daerah (LOD) melakukan audiensi dengan Pemkab Sleman pada 6 Juli 2012 yang dihadiri oleh Wakil Bupati Sleman, Kepala Kantor Perijinan, dan sejumlah pejabat dari instansi terkait. Audiensi oleh LOD yang dilatarbelakangi laporan dari Gandhul (Gerakan Pedagang Peduli Pasar Godean) pada tanggal 8 Maret 2012 ke Lembaga Ombudsman Daerah Yogyakarta tentang keresahan pedagang Pasar Godean yang merasakan adanya penurunan omset akibat beberapa toko modern yang berjarak kurang 30-40m dari pasar tradisional. menunjukkan bahwa pihak LOD dan pedagang tradisional sebagai pemangku kebijakan (stakeholder) kurang dilibatkan dalam formulasi dan implementasi kebijakan.

Selanjutnya dilakukan koordinasi antara Disperindagkop, Dinas Pasar, Satpol PP dengan pedagang pasar tradisional serta pengusaha toko modern. Untuk meningkatkan daya jual pasar tradisional, Dinas Pasar bekerjasama dengan Kecamatan Godean telah melakukan penertiban pedagang pasar Godean sehingga tidak menganggu badan jalan. Persaingan harga ditanggulangi dengan melakukan kerjasama dengan toko 
modern untuk kulakan bersama sehingga dapat diperoleh harga dasar termurah dari distributor. Pengendalian jumlah pasar modern juga dilakukan dengan penataan ruang. Kepala Bappeda Sleman menyampaikan bahwa pusat perbelanjaan besar hanya diijinkan untuk didirikan di pusat wilayah sistem perkotaan sehingga tidak menganggu omset pasar tradisional.

Sedangkan untuk wilayah lain di Kabupaten Sleman dimana jarak toko modern cukup dekat dengan pasar tradisional, cukup mendapat toleransi terbukti dengan munculnya SK Dispensasi pada akhir tahun 2011 yang mengatur dispensasi bagi 91 toko modern yang telah mengajukan ijin pendirian toko modern sebelum adanya Perbup No. 13/2010 dan 45/2010. Sedangkan 82 toko modern yang lain belum mendapat ijin dikarenakan jarak yang terlalu dekat dengan pasar tradisional, sehingga dapat dikatakan bahwa implementasi kebijakan belum berhasil. Jika kebijakan ditegakkan sesuai Perbup tentunya toko modern yang melanggar aturan perizinan dan penataan lokasi segera ditutupatau direlokasi dengan berbagai resiko kerugian yang harus dihadapi oleh pemerintah lokal karyawan toko modern berjaringan nasional dan pemilik waralaba toko modern. Kerugian waralaba toko modern berjaringan nasional sebenarnya bisa diatasi dengan menjadikan toko modern lokal yang tidak terkait dengan modal atau saham toko modern jaringan nasional. Oleh karena itu, political will dari birokrasi sangat menentukan keberhasilan kebijakan.

Menurut Parsons (1995), model implementasi top down merupakan model rasional yang berisi gagasan bahwa implementasi menjadikan orang melakukan apa-apa yang diperintahkan dan mengontrol urutan tahapan dalam sebuah sistem. Mazmanian dan Sabatier (1983) dalam Ratmono (2008) berpendapat bahwa implementasi top down adalah proses pelaksanaan keputusan kebijakan mendasar.

Menurut Peraturan Bupati No 45 tahun 2010, pusat perbelanjaan dan toko modern wajib memiliki beberapa jenis perizinan. Jenis perizinan tersebut adalah Surat Izin Usaha Perdagangan (SIUP), Izin Peruntukan Penggunaan Tanah (IPPT), Izin Mendirikan Bangunan (IMB), Tanda Daftar Perusahaan (TDP), dan Izin Gangguan (HO). Di Kabupaten Sleman sendiri, dari data yang diperoleh di Kantor Pelayanan Perizinan (KPP) dan Disperindagkop, belum ada satupun toko modern yang memiliki izin yang lengkap. Sebagian besar baru mengantongi HO bahkan masih banyak yang belum mengurus izin usaha perdagangan.

Menurut Peraturan Bupati No 13 tahun 2010, aspek jarak toko modern dan pusat perbelanjaan dengan pasar: (a) minimarket, 500 meter dari toko tradisional dan 1000 meter dari pasar tradisional; (b) department store dan perkulakan, 500 meter dari toko tradisional dan 1500 meter dari pasar tradisional; (c) hypermarket dan pusat perbelanjaan, 500 meter dari toko tradisional dan 2000 meter dari pasar tradisional. Berdasarkan data disperindagkop, cukup banyak toko modern berjaringan nasional yang melanggar aturan penataan lokasi yang hingga saat ini bertambah, bukan berkurang, karena banyak yang berdiri tanpa izin dan tanpa memperhatikan penataan lokasi. Berdasarkan pengamatan di lapangan, hampir di setiap pasar tradisional, akan dijumpai pasar modern (toko modern berjaringan nasional), apabila dalam Perbup tidak disebutkan dengan jelas berkaitan toko modern yang melanggar penataan lokasi dan perizinan dan mendapatkan SK Dispensasi, dalam peraturan terbaru Perda No. 18 tahun 2013 cenderung masih toleran dengan keberadaan toko modern berjaringan nasional dan segi konten dan konteks 
kebijakan untuk diimplementasikan tergolong kurang jelas.

Sedangkan kejelasan konten dan konteks baru ditemui dalam Perda No. 18 Tahun 2012 pasal 27 yang secara jelas menyebutkan syarat dan sanksi berkaitan Izin Usaha Pusat Perbelanjaan (IUPP) dan Izin Usaha Toko Modern (IUTM). Meskipun tergolong bersifat lunak akan keberadaan toko modern yang terlanjur berdiri.

\section{Peran Pemerintah Lokal dalam Imple- mentasi Kebijakan}

Menurut Osborne dalam Reinventing Governance, perlu mendudukkan peran pemerintah lebih sebagai katalisator, regulator, fasilitator, pengarah, pembina, dan pengawas penyelenggaraan urusan pemerintahan. Keberadaan berbagai fungsi tersebut dapat diarahkan juga bahwa pemerintah lokal berfungsi sebagai pelayan publik dengan menjalankan berbagai fungsi tersebut, tidak hanya sebagai regulator atau pembuat, pengawas dan pelaksana aturan saja tetapi adanya peraturan harus berpihak pada masyarakat (pro publik) dan pro poor.

Berdasarkan pernyataan Kepala Disperindagkop, "Kendati sering mendapat tentangan khususnya dari kalangan pedagang pasar tradisional, pihak Pemkab mengaku tidak dapat berbuat banyak. "Toko modern memang menimbulkan pro-kontra di tengah masyarakat. Dalam persoalan ini kami coba merespon kepentingan semua pelaku ekonomi."

Disperindagkop tidak memungkiri bahwa daerah butuh investasi. Jika mengacu peraturan, masih ada peluang bagi investor untuk menanamkan modal di usaha ini. Kesempatan mendirikan toko modern terbuka di sejumlah daerah pinggiran seperti Kecamatan Prambanan, Moyudan, Minggir, Cangkringan, dan Turi. Pasalnya secara kuota, lima kecamatan itu masih memungkinkan. "Kuota kami keseluruhan 106 toko jejaring, dan dihitung per kecamatan. Sampai sekarang hanya wilayah itu yang masih mungkin ditambah bangunan toko modern, lainnya sudah penuh," ujar Pranowo (Suara Merdeka, 4 Mei 2012).

Pernyataan disperidagkop dan keleluasaan di kabupaten Sleman untuk membangun pusat perbelanjaan seperti mall semakin memperkuat bahwa kebijakan bersifat pilihan rasional dari birokrat dan top down. Peran pemerintah dapat dikatakan sebagai regulator atau pembuat aturan, belum sampai pada level katalisator, fasilitator, pengarah, pembina dan pengawas penyelenggaraan urusan pemerintahan yang bermuara pada fungsi pelayan publik.

\section{Implementasi Kebijakan dari Aspek Sistem Organisasi Kebijakan}

Teori manajemen strategis Thompson menggambarkan sistem organisasi terkait lingkungan (environment) - nilai (value) - sumber daya (resource) atau EVR, yang dapat dikaitkan dengan berbagai teori model implementasi kebijakan yang menyebutkan salah satu atau semua unsur EVR. Terdapat beberapa tipe sinergisitas sistem organisasi yang dapat diamati pada Gambar 2.

EVR dikatakan kongruen ketika terjadi irisan antara lingkungan, nilai dan sumber daya (EVR) berdasarkan analisis SWOT serta kepemimpinan dan nilai yang baik. Dikatakan sebagai lost organization ketika tidak terjadi sinergi atau keterkaitan antara EVR. Organisasi dinyatakan tidak kompeten ketika yang beririsan yaitu EV. Organisasi dinyatakan kurang kompeten ketika yang beririsan ER dan dinyatakan penyimpangan strategis ketika yang beririsan VR saja.

Environment dalam kebijakan perencanaan penataan toko modern, yaitu: a) Ekonomi: mata pencaharian masyarakat baik yang bekerja di ritel modern maupun ritel tradisional, pemegang saham, retribusi pemerintahan lokal melalui IMB, HO, SIUP, IUTM, IUPP; b) Politik: political 


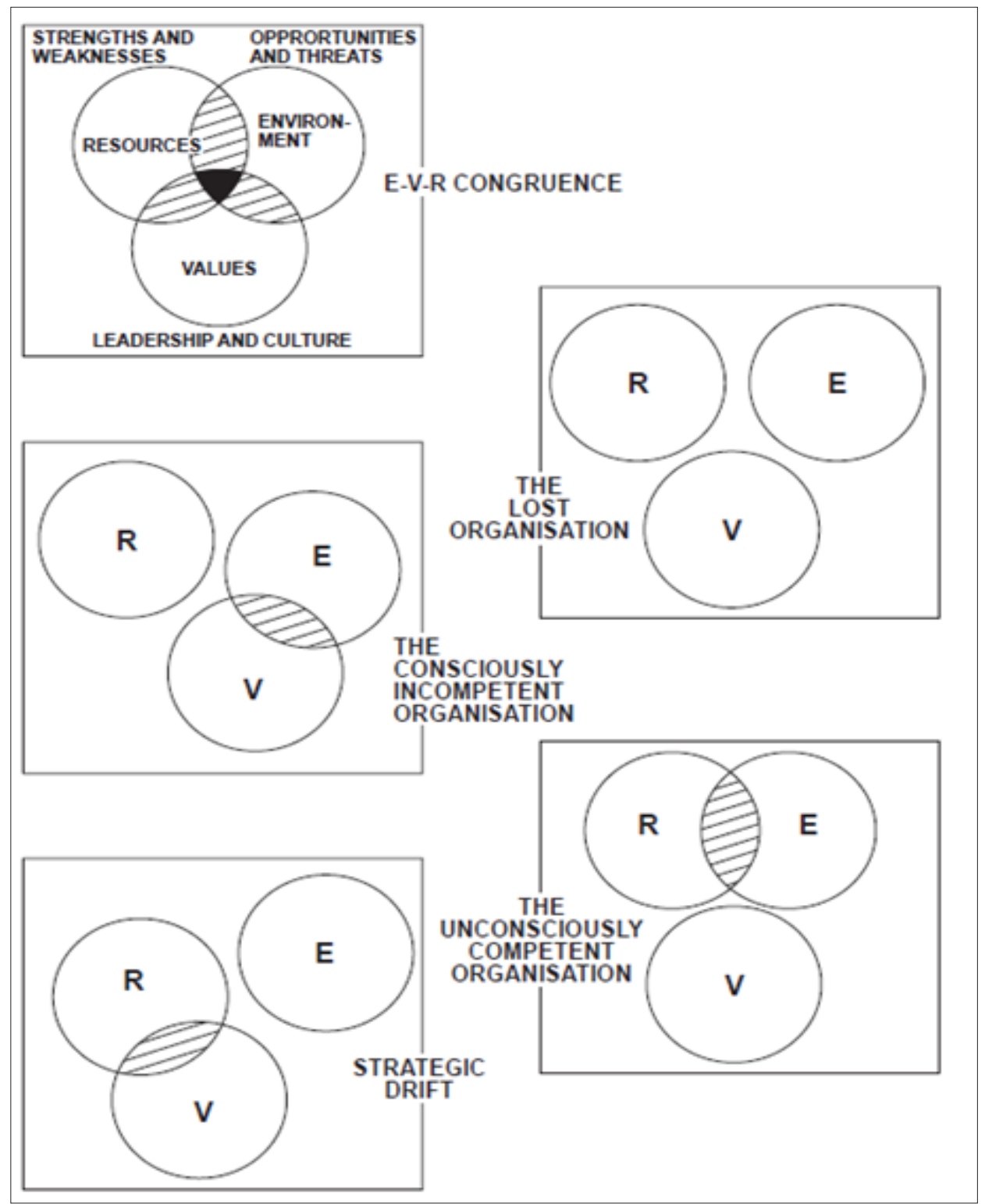

Gambar 2. EVR Analysis (Sumber: Thompson)

will pemerintah lokal sebagai regulator atau pelayan rakyat; dan c) Sosial budaya: perubahan pola gaya hidup masyarakat (modernisasi).

Value, yaitu pemahaman dan relevansi teori dan praktek ekonomi politik kebijakan dan good governance oleh pemangku kebijakan khususnya pemimpin daerah dan birokrasi. Sedangkan resources dapat dikaitkan dengan pemangku kebijakan yang terdiri dari: a) pedagang ritel kecil/tradisional, b) Pihak ritel modern, c) Pemerintah lokal: bupati, DPRD, Disperindag, BAPPEDA,
Dinas Pasar, d) KPPU dan KADIN, e) Pusat Studi Kerakyatan dan LOS DIY. Pihak yang bertanggungjawab di lapangan (operator lapangan); a) Disperindagkop, b) Satpol PP, c) KPP.

Lingkungan dalam kebijakan perencanaan toko modern berjaringan nasional yaitu lingkungan ekonomi setiap pihak yaitu pemerintah/negara (state) yang mendapatkan keuntungan dana dari perizinan toko modern, posisi untuk melayanikepentinganmasyarakat/publikatau penjaga keseimbangan pasar tradisionalmodern; kekuatan perusahaan (pemegang 


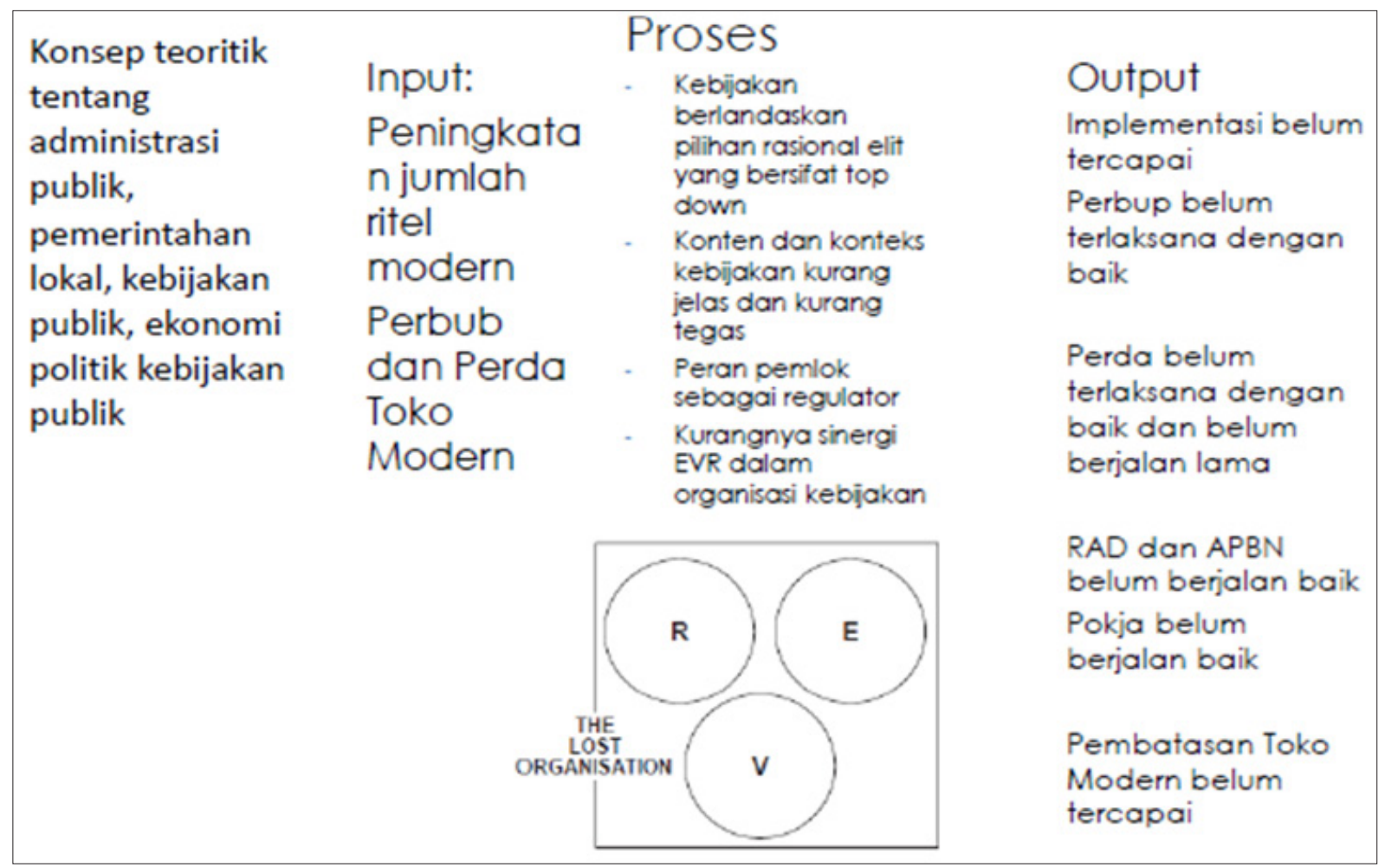

Gambar 3. Existing Model Kebijakan Perencanaan Toko Modern

saham utama) yaitu memperluas jaringan bisnisnya; kepentingan pemilik toko modern waralaba untuk mendapatkan, kepentingan pemilik toko tradisional (usaha kecil menengah), karyawan toko modern yang berasal dari masyarakat yang memerlukan lapangan pekerjaan, masyarakat untuk mendapatkan layanan dan fasilitas yang baik dalam kegiatan jual beli. Politik berkaitan dengan political will dari birokrasi dan aparat sebagai penegak hukum apakah mau berpihak kepada kepentingan pemilik toko tradisional (usaha kecil menengah) atau kepentingan pengusaha besar (domestik-asing)?

Sedangkan berkaitan dengan value atau nilai good governance dan ekonomi politik kebijakan publik, dalam pilihan rasional dan top down seringkali menjadikan pemerintah (birokrasi dan aparat) bertindak untuk kepentingan pribadi dan pengusaha besar (market).

Dalam level lapangan, menunjukkan kurangnya koordinasi antara Disperindagkop, KPP dalam validitas data toko modern sehingga menyulitkan tindakan di lapangan. Seharusnya dinas pasar pun berperan aktif memantau dan menambahkan data berkaitan toko modern yang berada di sekitar pasar tradisional. Sedangkan dalam level birokrasi di atasnya pun memiliki pendapat yang berbeda, seperti dari Disperindagkop yang masih membuka peluang berdirinya toko modern di kecamatan yang masih kurang keberadaan toko modern dan mendasarkan prinsip keseimbangan pasar, disisi lain berdasarkan pernyataan Komisi A DPRD dalam menyikapi empat toko modern yang tidak memiliki izin, "Buat apa kami membuat perda kalau nanti hanya untuk hiasan saja. Kalau memang melanggar perda baru ini mungkin masih bisa mendapatkan toleransi, namun ada dua peraturan lama yang sudah ada namun tetap tidak diindahkan". Hal ini harus menjadi catatan penting lemahnya kontrol hukum di Sleman. Artinya dari segi resources atau pemangku kebijakan masing-masing memiliki pendapat yang 
berbeda dan kurang atau tidak terjadi sinergi. Antara ketiga elemen EVR tidak terjadi sinergi.

Ekspansi retail yang agresif sebagai salah satu dampak dari globalisasi ekonomi yang memicu pengejaran kepada konsumen dengan pusat perbelanjaan (mall) sebagai media komersialisasi, menjadikan ruang kota menjadi terdikte. Hal ini memunculkan fenomena retailisasi di kota-kota besar di Indonesia bahkan sampai ke pelosok desa. Gejala ini relatif sulit dikendalikan karena berlaku sistem pasar, yang digerakkan oleh supply and demand, dimana hadirnya konsep belanja modern telah mewabah sebagai produk dari kapitalisme global. Aspek yang muncul terkait dengan fungsi keruangan adalah munculnya alih fungsi lahan ke arah retailisasi, penurunan daya dukung lingkungan kota, munculnya kemacetan dari kegiatan retail pada lokasi-lokasi strategis dan dampak sosial dari kegiatan retail modern terhadap eksistensi dari pasar tradisional dan retailer kecil sebagai basis ekonomi kerakyatan bagi usaha kecil, mikro dan menengah.

Kebijakan pembatasan ritel modern ini tentunya diusahakan memberikan win-win solution pada pihak-pihak yang berkepentingan yaitu: a) Pedagang ritel tradisional/kecil agar mata pencahariannya tidak terancam; b) Ritel modern yang diperlukan kalangan tertentu dan kondisi tertentu yang juga menyediakan lapangan pekerjaan bagi masyarakat; dan c) Pemerintah lokal sebagai pihak yang berwenang dalam menentukan kebijakan;

\section{SIMPULAN}

Implementasi Kebijakan Perencanaan Penataan Toko Modern Berjaringan Nasional kurang berjalan dengan baik disebabkan kurangnya sinergi Environment Resources and Value (EVR) dalam sistem implementasi kebijakan yang cenderung dapat dikatakan sebagai lost organization, masing-masing EVR cenderung berdiri sendiri.

Peran pemerintah dapat dikatakan sebagai regulator (pembuat aturan saja) yang ditunjukkan dengan formulasi dan implementasi yang kurang melibatkan partisipasi kelompok kepentingan seperti LSM, Kadin, KPPU dan masyarakat akhirnya kebijakan menjadi kurang pro poor dan pro publik.

Implementasi Kebijakan Perencanaan Penataan Toko Modern Berjaringan Nasional akan berjalan dengan baik dengan sinergi Environment Resources and Value (EVR) dalam sistem implementasi kebijakan sehingga peran pemerintah sebagai pelayan masyarakat yang ditunjukkan dengan formulasi dan implementasi yang melibatkan berbagai pemangku kebijakan termasuk partisipasi kelompok kepentingan seperti LSM dan masyarakat atau dengan kata lain kebijakan bersifat bottom up dan deliberatif, akhirnya kebijakan akan menjadi pro poor dan pro publik.

\section{DAFTAR PUSTAKA}

Antara. 2011. Warga Sleman Tutup Paksa Toko Modern, 9 Juni 2011, http:// www.edisicetak.joglosemar.co/ berita/warga-sleman-tutup-paksatoko-modern-45856.html, diakses pada 1 November 2012,

Effendi, S. 2004. Sistem Pemerintahan Negara Kekeluargaan, Pidato Dies Natalis XVIII Universitas Wangsa Manggala. Yogyakarta, 09 Oktober 2004.

Emzir. (2010). Metode Penelitian Kualitatif. Rajawali Press. Jakarta.

Hapsari, A. 173 Toko Modern Berdiri di Sleman, 4 Mei 2012, http:// suaramerdeka.com/v1/index.php/ $\mathrm{read} / \mathrm{news} / 2012 / 05 / 03 / 117333$, diakses pada 1 November 2012 .

Imawan, R. (1999). Kebijakan Publik. Yogyakarta: Program Studi Magister Administrasi Publik, Universitas Gajah Mada. 
Liputan6.com. Pedagang Pasar Godean, Protes minimarket, 7 Maret 2012, http: / / news.liputan6.com / read/380765/pedagang-pasargodean-protes-mini-market, diakses pada 1 November 2012,.

Mulyana, D. (2001). Metodologi Penelitian Kualitatif. Bandung: PT Remaja Rosdakarya.

Nasution, S. (1996). Metode Penelitian Naturalistik Kualitatif. Bandung: Transito.

Parsons, W. (1995). Public policy: An introduction to the theory and practice of policy analysis. Northampton, MA: Edward Elgar.

Ratmono. (2008). Analisis Kebijakan Publik (Konsep,Teori,dan Aplikasi). Yogyakarta: Pustaka Pelajar.
Santosa, A. dan Indroyono, P. (2011). Pedagang Pasar Tradisional Terancam, Jurnal Ekonomi Rakyat.

Suryono, A. (2006). Ekonomi Politik Pembangunan dalam Perspektif Teori Ilmu Sosial. Malang: UM Press.

Prenanto, T.A.S. 2011. Indomart Pembunuh Pasar Tradisional, 3 Mei 2011, http:// sosbud.kompasiana.com/2011/05 /03/indomart-pembunuh-pasartradisional-360746.html, diakses pada 1 November 2012.

Todaro, M.P. dan Smith, S.C. (2006). Economic Development, Ab. Andri Yelvi (2009), Pembangunan Ekonomi Jilid 2. Edisi 9. Jakarta: Penerbit Erlangga. 